\title{
Framing knowledge and innocent victims. Europe bans smoking in public places
}

\author{
Lars Thorup Larsen
}

For citing, please use this reference to the final, published version:

Larsen, Lars Thorup (2010) 'Framing knowledge and innocent victims. Europe

bans smoking in public places', Critical Discourse Studies, 7: 1, 1-17.

The published version can be accessed through this link:

http://www.tandfonline.com/doi/abs/10.1080/17405900903453914

\begin{abstract}
:
Most European countries have adopted partial or comprehensive smoking bans in public places within a short period of time although the underlying evidence on the risk of second-hand smoke is almost twenty years old. After giving a short overview of European smoking bans, the article aims to analyze and discuss what can explain this wave of smoking bans, not only regarding the similarity of the ban itself, but also of the arguments proposed in favor of the bans. While typical explanations in public policy studies fall short of explaining the momentum and similarity of smoking bans, the article discusses how the selective framing of knowledge and innocent victims can help to explain the strong impact of this particular policy proposal.
\end{abstract}

Keywords: Smoking ban; Tobacco control; Knowledge; Framing; Topoi; Science;.Discourse

\section{Introduction}

In March 2006, a new and severe smoking policy took effect in the small Californian town of Calabasas. This policy constitutes the first set of regulations to ban smoking not just within enclosed public spaces, but also outside. The new rules prohibit smoking at any outside location where a non-smoker is within a 20 feet radius or where such a person can be expected to arrive anytime soon, something smokers are legally required to be able to anticipate (City of Calabasas, 2006, chap. 8.12.040). The city penalizes all smoking that does not take place behind closed doors in your own home, and even smoking in your own car with the window open is prohibited, all with the objective to protect 'the public' and maintain what is termed a 'family-friendly atmosphere' in the city (City of Calabasas 2006, chap. 1).

This rather extreme example was debated in Danish news features around the time when the government proposed its own indoor smoking ban. While the news features seemed unsure how to categorize the Californian outdoor ban - is it the future for us or health advocacy gone too far? - there was no doubt about the framing of the national proposal. Banning smoking in public places seems like the only natural response to new knowledge about the risk of 
smoking, an argument which has traveled across Europe at a remarkable pace the past few years.

The analytical question is how the framing of smoking bans is related to actual policy development. What arguments can account for the urgency of the present wave of European smoking bans, and how are they framed? Although difficult to measure or test, it is possible to discuss how framing can impact upon policy development and to pit it against alternative explanations. It is not possible in one article to both engage in a long discussion of alternative explanations and to perform a comprehensive discourse analysis of all arguments relevant to a complex issue involving many actors and countries. It is necessary, however, to discuss the alternative explanations in order to see why an argumentative analysis of smoking bans is needed, and it is also vital to keep the cross-national perspective, because the article aims to understand the urgent wave of smoking bans and not any country in particular.

With these choices in mind, the argumentative analysis offered in the latter part of this article does not offer a complete mapping of smoking discourses, but a more limited analysis of the structure between several arguments widely used in the promotion of smoking bans. The principal point is that while new knowledge is in itself is a quite poor explanation, we should focus on the way knowledge is framed as a political imperative, which will be analyzed using the concepts of frame and topoi. This allows for an understanding of smoking bans in which a number of commonplace arguments work in conjunction in order to make public place smoking bans appear as the only natural response to the present state of risk knowledge. Besides knowledge, the key elements in the framing of smoking bans are a specific conception of innocent victims and the separation between private and public spheres of legitimate intervention.

Before the frame analysis in the second part, however, the first part of the article gives a brief overview of the present international trend of smoking bans and then goes on to a critical discussion of various alternative explanations. Since knowledge-intensive policy changes are often understood as being overly automatic, it is important to assess the underlying premises of these different explanations and thereby clarify what the subsequent frame analysis should help us to understand better.

\section{A new wave of smoking bans}

California was the first place to ban smoking in restaurants in 1994 and later extended the ban to cover all places serving food or drinks in 1998. The ban is essentially a workplace safety regulation, so its main objective is to protect employees and not the general population against environmental tobacco smoke (ETS) (Helsedepartementet 2003: chap. 1.4.3).

The pattern of public place smoking bans is quite uneven across the US because of the federal structure. Most of them have been initiated within the past 4-5 years, and at present, about a dozen states plus a large number of cities have comprehensive smoke free legislations (Smoke Free World, 2008). The most widely known example is probably New York State's Clean Indoor Air Act of 2003, which prohibits smoking in all enclosed public spaces including bars, restaurants, workplaces, public transportation, sport, education and leisure facilities (State of New York, 2003). It also removes all loopholes for smoking rooms and zones in the earlier legislation covering New York City (NYC Health, 2002), so the 
only remaining exemption is for the very few 'cigar bars' that are not allowed to either move or expand their business.

Simultaneously with the New York development, the first comprehensive laws were passed in Europe leading to Irish and Norwegian public spaces being entirely smokefree by 2004 after some years with various partial workplace restrictions (Smoke Free Partnership 2006, pp. 118-9, 123-4). The Irish law prohibits smoking in all enclosed public spaces including workplaces, public transportation, pubs, and restaurants with no options for dedicated smoking rooms (Department of Health 2004, chap. 47). Apart from outside locations and private homes, the only exceptions are for prisons, psychiatric facilities, and a small number of hotel rooms (Smoke Free Partnership, 2006, p. 117). The Norwegian law is very similar and likewise defines bars and restaurants to be entirely smokefree, although smoking rooms are allowed outside of the hospitality sector (Helsedepartementet, 2003, chap. 7).

The following year (2005) saw a series of new smoking bans in Portugal, Sweden and Italy all of which have possibilities for smoking rooms, although many efforts are made to limit the comfortableness of such cells. The Swedish smoking rooms, for example, prohibit any entry of waiters, bartenders, food or drink into the smoking rooms (Socialdepartementet, 2003, p. 5). Since 2007, all parts of the United Kingdom have comprehensive smoking bans modeled on the Irish law (Department of Health, 2006a), and France has begun an expedient process towards a similar ban. Belgium and Denmark have introduced partial bans with exceptions such as in small bars or single-person offices (Regeringen, 2007), and while Germany has long been the laggard of tobacco control in Europe due to both federalism and historical reasons (Frankenberg, 2004), a minimal federal ban is now initiated with partial bans on the regional level.

Table 1 gives a brief overview of nine European countries with a general distinction between having no significant exceptions (comprehensive ban) or options for smoking rooms (partial ban). The two right columns indicate a country's score on the Joossens \& Raw scale that includes tobacco control instruments such as taxes, public place bans, information, advertising bans, health warnings and treatment (Joossens \& Raw, 2006, p. 251; 2007, p. 8).

[ Table 1 around here ]

\section{What explains the wave of smoking bans?}

In the coming years more European countries will most likely join this wave and several of the partial bans will have their exceptions removed. Being in this transitional phase makes it difficult to make a simple comparison of adopters and nonadopters, because the observed differences could just be a variation the pace of each country's implementation process. The table paints a relatively messy picture in terms of what pattern characterizes the development of smoking bans across Europe. For example, some of the continental smoking bans allow smoking rooms in bars, while other countries have smokefree bars, but exceptions in other workplaces, etc.

It is difficult to match this pattern with the most typical explanations used in comparative studies of public policy, because the bans are not indicative of different health problems in each country nor can they simply be ascribed to differ- 
ences in the different institutional landscapes. For instance, whereas German federalism has effectively prevented a comprehensive smoking ban, American federalism has the reverse effect, because advocacy groups have had more venues to choose between (Marmor \& Lieberman, 2004, p. 289; Marmor, 2006, p. 382). The impact of a pluralistic policy process is similarly ambivalent. Some places, pluralistic hearing processes led to more exemptions, like the Danish exemption for single-person offices and homeless shelters. On the contrary, the influence of interest groups like the pub trade was a major factor in shifting the UK from the partial ban originally proposed to an Irish style comprehensive ban. The impact of national policy styles is also unclear, because while one would expect Sweden to have strict smoking ban along its tradition for behavioral regulation and reliance on expert knowledge, they have more exemptions than for example Norway, Ireland, the UK, and France.

Another explanation could be that strict smoking bans reflect the level of support for such measures in public opinion. This does not work either, since support only seem to increase after the ban has been enacted (Smoke Free Partnership, 2006, p. 91). Only the Italian case showed strong public support for a ban well in advance of the government's decision (Smoke Free Partnership, 2006, p. 95), but this led to a partial regulation. In summary, the European pattern of smoking bans does not fit a simple explanation. Although it is possible to establish complex explanatory models (see Studlar, 2007), another consideration is whether we are in fact not asking the wrong question. Perhaps we should reverse the question and ask what explains the striking similarity and simultaneity of European smoking bans. The differences discussed above are still very small compared with the much more scattered and unevenly timed development in the US. And since there is no top-down coordination of policies in Europe, we should try to find out why smoking bans are simply an 'idea whose time has come' (Kingdon, 1984, p. 1)?

\section{Convergence of public place smoking bans}

Besides considering policy variation, we must also discuss alternative explanations for why the policy development seems so similar across Europe. One of the most frequent explanations used in policy documents and public statements is that a ban on smoking is a direct response to new knowledge about the dangers of second hand smoking. For example, the French Prime Minister Dominique de Villepin presented his country's smoking ban in October 2006 as the simple exercise of '... adapting public health to necessity' (de Villepin, 2006).

Many approaches in public policy studies try to take such ideas seriously and stress the impact of various epistemic, discursive or ideational phenomena on policy development. For instance, one could try to explain the wave of smoking bans by referring to a new set of ideas (Goldstein \& Keohane, 1993; Blyth, 2003), policy paradigms (Hall, 1993), advocacy coalitions (Sabatier, 1993), policy communities (Rhodes \& Marsh, 1992, p. 187), or epistemic communities (Haas, 1992). Disregarding what separates these positions, most of them would try to explain the convergence of smoking bans by some set of 'shared beliefs' among actors in the field, not least the belief that second hand smoking causes heart and lung disease. Such a belief definitely exists among actors such as the Association of European Cancer Leagues, the European Heart Network, the European Respiratory Society, the European Network for Smoking Prevention (Smoke Free Partnership, 2006, p. 142), and in particular the World Health Organization (2004) 
whose Framework Convention on Tobacco Control (FCTC) aims to homogenize policy instruments among member states (WHO, 2003).

The alternative explanation proposed in this article bears some resemblance to these ideational approaches, because a policy frame is also of a discursive nature. Instead of actually analyzing discourse and policy arguments, many ideational of these approaches in public policy study actors who are believed to have certain 'shared beliefs'. This is problematic for various reasons. First, ideational explanations often draw on either Kuhn's scientific paradigms or Lakatos' research programs as a metaphor for the structure of shared policy ideas. Such analogies will easily overdramatize the extent and implications of value consensus, however, which is a considerable downside of the actor-centered approaches (see Larsen 2009a). For example, one could argue that while some labor unions share the belief in workplace smoking bans, they might do so for different reasons than radical anti-tobacco groups whose end goal is the 'smoke free society' (Smoke Free Partnership, 2006, p. 119; Roemer, 2004, p. 692). So although the policy shift is clearly ideational, this does not necessarily involve an underlying set of shared, fundamental beliefs; and even if consensus does exist on some points, this may well be an effect and not a cause, since these networks deliberately aim to 'speak with one voice' (Smoke Free Partnership, 2006, p. 146).

Second, even if we downplay the aspect of consensus and see the antitobacco networks as a new social movement, this is not unproblematic either. Nathanson $(1999 ; 2005)$ compares the American development of tobacco control with gun control by using social movement theory, and while this approach does have potential, it still tends to focus more on the people involved and less on the actual ideas in favor of smoking bans. It will mainly tell us who supports smoking bans, but not why they do so, or why policy makers now appears to be listening to the critical arguments against tobacco.

Third, if we look at what ideas are actually important, the causal belief that both active and involuntary smoking causes cancer is generally accepted. On other hand, since this causal relationship has been accepted for a very long time, it is a poor explanation of the current wave and also a poor explanation of why all countries choose to focus on public places. The tobacco literature illustrates a long list of measures used to contain the so-called tobacco epidemic (Feldman \& Bayer, 2004, pp. 6-7; Roemer, 2004; World Health Organization, 2004, pp. 95116; de Beyer \& Brigden, 2003; Studlar, 2002, pp. 242-3; Wolfson, 2001, pp. 1943), but the present debate seems to put the most faith in the health effect of smoking bans in public places, and with a focus on bars and restaurants in particular. In other words, the ideas behind smoking bans are not necessarily new and often involve priorities for specific policy instruments rather than just medical risk knowledge.

\section{Framing and discourse}

After discussing alternative explanations for the convergence of smoking bans, the remainder of this article attempts to outline an alternative account of what makes public place smoking bans so effective. This section specifies the theoretical concepts, which is a combination of frame and discourse analysis. The analysis draws on sources of different genres - such as policy documents, reports, 
NGO papers, and campaigns - in order to paint a broader picture of smoking policy discourse (cf. Wodak 1999: 188), which may on the other hand come at the expense of data set ready for testing hypotheses in a strict fashion. As the previous should indicate, it is necessary to use a type of analysis that actually goes into the argumentative landscape of smoking bans in order to see why this policy proposal has become so prolific.

Although the concept of framing has received considerable attention in the past few decades, no consensus has evolved about its definition. Others have associated the concept of framing with such fields like communication (Entman, 1993); social movements (Snow \& Benford, 1988), political psychology and public opinion (Chong \& Druckman, 2007), but here it is used with a reference to policy studies where it designates a selective presentation of an issue (Stone, 2002; Rein \& Schon, 1994; Fischer, 2003). The dual perspective here of frame and discourse is inspired by the overview given in Hajer and Laws (2006), but without incorporating individual beliefs, which are less important in this case.

Frame and discourse are often used interchangeably, which is no coincidence, since the two phenomena are clearly related. The difference is that while discourse is often taken to imply an underlying structure of meaning and linguistic elements, frames are used to identify more general characteristics of the way an issue is presented. Also, framing is understood as a more or less deliberate attempt to present an issue in a selective manner in order to make certain perceptions and consequences more likely. They are constructed as a strategic political tool, which is not to say for instance that all the presented facts and numbers in a smoking ban frame are necessarily false, only that they are framed in a very selective manner in order to shape our perception of the issue. Whether they succeed in shaping our perception is an entirely different matter.

Discourse is obviously a much broader concept, but is understood here as the reservoir of meaning that frames draw on, i.e. what actually constitutes the content of the frame aside from references to facts, events, etc. It is not the intention here to analyze the entire discourse around smoking in great detail, but only to identify some of the most important discursive elements that give meaning to the current framing of smoking bans. I draw here mainly on the concept of topoi used in parts of in Critical Discourse Analysis (CDA) (Wodak et al., 1999, p. 34; Wodak \& Reisigl, 2000; Reisigl \& Wodak, 2009), which designates commonplace arguments employed in public discourse to facilitate specific conclusions: As defined by Grue, "A topos [plural topoi] is both a place of common knowledge (cf. commonplace) and a conclusion rule or warrant that may be invoked in discourse interpretation" (2009, p. 309). It is a powerful tool in political discourses because it connects a background of common knowledge with a conclusion or certain course of action, such as a political decision.

Although discourse has a structural basis, topoi are thus also active ingredients in a frame because they specify what conclusions should follow if such and such circumstances are met. They are semi-automatic in the sense that if, for instance, a topos of scientism is invoked, certain conclusions are close at hand in the discourse about what is the right course of action. The reservoir of common knowledge in a topos will often have a historical origin, but functions as a given in the present similar to what Foucault termed the 'historical a priori' (Foucault, 1969; cf. Jäger \& Meier, 2009).

The topical landscape around smoking bans can also be characterized by referring the various topoi to the forms of legitimation they depend upon. In an 
updated version of both Weber's and Habermas' typologies, Leeuwen's taxonomy distinguishes between legitimation by reference to authority (e.g. law), rationalization, moral evaluation or mythopoesis (storytelling) (Leeuwen, 2007) and although this article does not offer an extensive legitimation analysis (see Leeuwen \& Wodak, 1999), the taxonomy will be used in the following to characterize how the topoi differ from one another.

As the main title of the article indicates, my claim is that smoking bans are usually characterized by a specific framing of knowledge and victims. The first and most significant part of the argument concerns the tricky relationship between knowledge and politics. While most policy documents as well as observers of the policy development point to the impact of tobacco-related risk knowledge, it is less obvious how we can use new knowledge as an explanation as is elaborated below (on knowledge and tobacco control, see also Larsen, 2008). The key point is that smoking bans are not explained by the current state of knowledge or science, but by the selective way in which knowledge is framed. This frame is characterized by a tension between a topos of scientism and a topos of knowledge as a weapon. The second part of the argument concerns the framing of victims in relation to what constitutes a legitimate space of public health intervention. Here, the tension is between a topos of the innocent bystander on one hand and the topos of private and public on the other.

The following sections discuss these two parts of the smoking ban frame. As mentioned in the introduction, the analysis does not claim to offer a systematic textual analysis text by text and country by country, but rather seeks to qualify the use of the policy frame and its inner tensions as an explanation by discussing each constituent part against various genres of policy documents as well as against certain theoretical considerations (cf. Wodak 1999, p. 188). Several points are based on the 2006 report of the Smoke Free Partnership, an organization comprising such networks as the Association of European Cancer Leagues, the European Heart Network, and the European Respiratory Society and whose reports gather many common understandings of smoking bans and have also traveled widely between European policymakers.

\section{Using knowledge to fight smoking}

This section aims to demonstrate that smoking bans are presently accompanied by a certain framing of knowledge with a tension between two component topoi. Although this analysis does not identify a specific topos of numbers (see Wodak \& Reisigl, 2000, p. 79), the representation of numbers and statistics in policy documents on tobacco serve as illustrations here of the tension between topoi and the general selectiveness of the frame.

The first component of the framing of knowledge I call the topos of scientism, an understanding previously identified in both tobacco control in general and in public health policy, although without using the concept of topoi (Larsen, $2008 ; 2009 b)$. It designates a commonplace argument saying that policy decisions such as strict smoking bans will and should follow directly from the objective scientific facts about the danger of smoking. Often, arguments following this topos will argue that 'with everything we now know', a strict smoking ban is the only natural response. In terms of legitimation, this topos clearly builds on expert authority (Leeuwen 2007, pp. 94f). 
The relationship between risk knowledge and smoking bans is far from being a simple and automatic causal relationship in practice, however, which goes to demonstrate the 'obligatory' characteristic of the topos (Wodak et al., 1999: 34). First, the timing is seriously off between cause and effect, which has also been termed 'the problem of timing' in tobacco control (Marmor, 2006, p. 383). Not only is it not a new idea to propose smoking bans in public places. They were also debated when the dangers of firsthand smoking first became widely accepted, not least when the US Surgeon General went on live TV in 1964 and boldly declared that smoking causes cancer. The evidence on secondhand smoking came much later with the first epidemiological studies appearing in the late 1960s (Samet, 2004, p. 289) and with concerns about the issue raised by the US Surgeon General as early as 1971. Not until the early 1980s, however, were the first controlled experiments able to document a causal relationship between second hand smoking and cancer. The turning point was 1986 when the US Surgeon General officially acknowledged this link in his yearly report on smoking and health. Similar acknowledgements were made the same year by institutions such as the US National Research Council and the International Agency for Research on Cancer (IARC) (Samet, 2004, p. 289).

Obviously, the evidence base on the risk of both first and second hand smoking has expanded since then, not only increasing the risk estimates, but also linking smoking with many other complications besides lung cancer. Even still, new knowledge is a very poor explanation of the current wave of smoking bans. If we had a theoretical expectation saying that new risk knowledge should lead to political regulation, the official recognition from 1986 should have been 'enough'. Even if we allow some room for political systems to respond slowly to such events, it still does not explain why definitive evidence that second hand smoking causes cancer had been lying around for almost 20 years when all of a sudden 5 6 years ago, most European governments suddenly decided to introduce more or less the same smoking ban. They began to frame an already existing knowledge base in a new way and drawing upon a topos of scientism saying that policies should mirror the current state of objectively given facts. But if new knowledge is clearly not the actual cause of all these smoking bans, why do so many actors in the field pretend that knowledge leads to action? Both the huge time gap as well as the quick jump from facts to norms should lead us to question the role of knowledge in political discussions as it is represented here by a topical landscape.

It is important to underline that not only scientists use the commonplace argument of scientism, but also a broad variety of agents involved in tobacco control such as politicians, health policy makers and administrators, but not least health advocacy interest groups. Among some of these agents, however, what looks like scientism may in fact represent what can be called a topos of knowledge as a weapon. While this argument will also often praise science, knowledge and facts, it does not expect conclusions to follow directly from them nor does it view science as a goal but rather as a means to an end. This second topos understands politics as a fundamental war between good and evil in which knowledge should be applied as a weapon in order to realize what is good. Its advocacy of strict smoking bans is just as unequivocal as in scientism, but here it is legitimized with a reference to moral evaluation and to some extent instrumental rationalization, or what Leeuwen terms 'means-orientation' (2007, pp. 102). 
The understanding of knowledge as a weapon is based on a perception of the tobacco area as being particularly bellicose, as this passage exemplifies:

It is clear that the motivation of Big Tobacco is greed. I believe greed that flourishes at the expense of the destruction of millions of lives every year can only be described as evil; it cannot be reconciled with personal and corporate ethics and morality. Such greed is infectious and pervasive (...) President Reagan called the Soviet Union, 'the evil empire', and President George W. Bush referred to Iraq, Iran, and North Korea, as 'the axis of evil'. Yet these entities to whom evils were attributed have not killed more than 400.000 citizens of the United States, or millions worldwide, each year. The evil empire is Big Tobacco and unlike military and political enemies who say, 'I intend to kill you if I can', Big Tobacco disguises its evil with the invitation to light up and become alive with pleasure. (Koop, 2004, p. xii)

The author is the former US Surgeon General C. Everett Koop, who preface Oxford University Press' 800-page volume on state-of-the-art tobacco knowledge (Boyle et al., 2004) with this message. The moral bluntness of these allegations is only all the more puzzling if we take into account the book's matter-of-factness as well as its status as state-of-the-art scientific evidence in the field, but it makes sense within the framework of the described topos.

If we move to anti-tobacco advocacy groups and governmental health departments, knowledge is also often employed as a weapon, because the morally correct conclusion is seen as given, or 'obligatory' as above. This is underlined not least in the choice between various types of tobacco-relevant knowledge. It is often difficult to determine the scientific status and character of this knowledge, especially because the same documentation often travels from advocacy groups to governmental reports and policy proposals, which indicates a general receptiveness towards knowledge that gives unequivocal recommendations for strict smoking bans. This does not mean that the impact of these arguments are automatic in practice, since several countries have made exemptions such as a smoking room clause against the advice of anti-tobacco groups.

A related question is what types of knowledge are involved. Until now, we have mainly discussed the link between epidemiological risk knowledge and the current wave of smoking bans, but tobacco-related policy documents also cite an increasing amount of social scientific research, such as public opinion data, reports on compliance with smoking and or on their economic effects. Looking closer at the various types of knowledge coming from advocacy groups such as the Smoke Free Partnership (2006), one can see the tension between the two topoi. This tension is not only a question of gathering knowledge in support of smoking bans, but also about the epistemological underpinnings of the different types of knowledge used to promote them. In a strange way, it appears as if actors such as the Smoke Free Partnership try to combine a blunt scientism underpinned by a positivistic epistemology on one hand with critical social constructivist epistemology on the other. Three examples illustrate this tension in the topical landscape.

First, the Smoke Free Partnership and many similar reports cite public opinion polls showing popular support behind smoking bans, but these are presented in remarkably selective and one-sided manner. This is surprising if we consider here that these reports are not streamlined to be communicated to the public, but are intended for policy makers and other professionals in the field to 
work with. For example, while public support varies anywhere between $30 \%$ and $95 \%$ of the various European populations, the status report of the Smoke Free Partnership does not pay any attention to this huge gap. It only concludes that 'the public supports smoke free legislation'; and where the support figures are perhaps not as high, they decide to focus on how much support rises after a ban is initiated (Smoke Free Partnership, 2006, pp. 7, 86-91).

The Smoke Free Partnership, the British Chief Medical Officer and other organizations such as the various National branches of ASH (Action on Smoking and Health) all take this ambiguous position on opinion polls. They argue on one hand that opinion polls are often biased against smoking bans in public places, because people have negative association to words like ban, restriction, or prohibition. Instead, the poll questions should be 'carefully worded' to avoid the 'confusion' that a smoking ban will actually involve a ban on smoking; instead, the questions should focus on health aspects and the protection of innocent lives, cf. below (Smoke Free Partnership, 2006, p. 85).

The British branch of ASH similarly use popular support in public opinion polls to legitimize bans, while they deliberately design the polls to demonstrate a high level of support. As they argue in a retrospective article on the lessons from their succesful smokefree campaign in England:

The poll also illustrated the very different answers you get depending on how the question is framed (...) For example, 90\% of Labour voters agreed that all workers had a right to a smoke-free environment but only $74 \%$ wanted all enclosed workplaces, including public places, smoke-free. When asked if they wanted pubs and bars smoke-free, only $49 \%$ answered yes. The poll was used to argue that if the government framed the issue as a yes/no issue of workplace and public health and safety, then it would get majority support for comprehensive legislation (Arnott et al., 2007, p. 424).

It is somewhat paradoxical that while these groups generally consider smoking bans to be the only rational response to new and undisputable scientific evidence, and while they also quote opinion polls supporting bans as being such undisputed facts, they seem to systematically discredit negative polls as being biased. Furthermore, they take an active part in constructing these results as to provide politicians with a ready set of positive figures. In other words, the argument seems to be that one should present facts in the way that promotes the desired goal as much as possible (topos of knowledge as a weapon), while this is backed by the view that tobacco-critical knowledge is scientifically superior (topos of scientism).

A second example of the intersection of science and opinion is when the polls try to measure the public's opinion on scientific facts themselves. For example, polls in many countries ask people if they think smoking is unhealthy and presents the results as the basis for a ban. The Smoke Free Partnership cites polls on how many citizens in each European country believe smoking to be unhealthy (2006, pp. 87-91). This resembles an argument found in the evaluation reports written about the smoking ban in New York. Amongst other issues, they asked people if they thought being in a bar is more healthy after the ban that it was before the enactment of the smoking ban, which surprisingly leads $15 \%$ to disagree! (State of New York, 2004). The Irish health department uses similar opinion figures in its one-year review and again without informing us why anyone in their right mind would not believe smoke free workplaces to be healthier (Office 
of Tobacco Control, 2005, p. 7). The point here is that these questions seem to build on simple facticity, which indicates a topos of scientism (if the workplace or the bar is safer without smoking, then smoking should be prohibited) while they use a very selective presentation of these numbers to advocate a solution already taken for granted (if facts support smoking bans, they should be considered scientific and unbiased. Knowledge is framed selectively, in other words, by drawing on two different standardized arguments about how to draw political conclusions from scientific facts.

Besides knowledge on public opinion, smoking bans are also promoted by other types of knowledge from the social sciences, especially on the economic consequences of smoking bans. In order to avoid the criticism that smoking bans are bad for business in the hospitality sector, the smoking ban proposals in countries like Ireland, Norway, Sweden, and the UK are all backed by economic reports disputing any negative impact on the economy whatsoever (Helsedepartementet, 2003, chap. 8; Office of Tobacco Control, 2005, p. 10; Socialdepartementet, 2003, p. 27; Chief Medical Officer, 2004). In these examples, it is similarly difficult to distinguish between how knowledge is used to frame arguments by governmental health departments on one hand and anti-tobacco groups like ASH on the other hand. This is surprising, because we would normally expect governments to build on a balanced evaluation of the best available knowledge while interest groups would be expected and perhaps forgiven for using a much more one-sided approach.

For example, established institutions such as the British Chief Medical Officer also use these questionable economic figures to support its call for a strict smoking ban. Both the Chief Medical Officer and the Smoke Free Partnership pay considerable attention to the case of New York (and to some extent California) in order to discard the view that smoking bans have negative economic effects for business (Chief Medical Officer, 2004, p. 23; Smoke Free Partnership, 2006 , pp. 52, 67, 79). The evidence shows that the hospitality sector in New York City experienced growth in several years after the Clean Indoor Air Act was enacted and more so than surrounding areas like New Jersey or Connecticut (Chief Medical Officer, 2004, p. 23). Even if we disregard that business figures for 2002 were probably influenced by 9.11 , it seems arbitrary to deduce anything from such uncontrolled statistical figures. If the growth of tourism in New York constitutes undisputable scientific evidence in favor of smoking bans, then it is hard to imagine what could not be framed as such. Some governmental health departments, in Norway and to some extent also Sweden, do seem to use more balanced economic estimates, however (Helsedepartementet, 2003: chap. 8.1; Socialdepartementet, 2003, pp. 26-7).

The framing of economic knowledge is more sophisticated than this, because it also involves the rejection of contradictory studies. For example, in almost identical formulations the UK and the pan-European reports judge all studies finding negative economic effects of smoking bans to be low-quality studies funded by the tobacco industry (Smoke Free Partnership, 2006, p. 65; Chief Medical Officer, 2004, p. 24). So, on one hand it is argued that knowledge is fundamentally biased by power and produced with a specific economic interest in mind, while facts in support of strict smoking bans are immediately accepted as the unbiased truth itself. The way that science leads to specific conclusions varies, one could say, depending upon whether scientism or the bellicose topos is invoked. Power struggles take the form of epistemological disputes here, especially about 
the issue of bias and for what purposes knowledge can and should be biased. Similar to how Schattschneider once defined organized interests as the 'mobilization of bias' (1975, p. 30), the framing of smoking bans is about the definition of bias and on which bases one can employ scientific knowledge for this purpose.

These examples demonstrate how the framing of knowledge plays a significant role in the various proposals and campaigns for public place smoking bans. On a number of issues ranging from health information to public opinion polls and economic analyses, public health reports on smoking carefully seem to preselect information and refuse to even mention questions that could compromise a smokefree environment. For example, none of the background reports begin to consider questions like social exclusion in spite of a highly uneven social distribution of smoking, nor do they consider the possible welfare costs of extending life expectancy. Not because smoking bans should be avoided on these grounds, but because questions like these could lead to much more muddled conclusions, which is not allowed in the rigid framing of science and knowledge in anti-tobacco arguments.

\section{Framing innocent victims}

The second part of the argument here concerns how the victims of involuntary smoking are presented in relation to the spheres of legitimate public intervention. There is also a tension here between two principles that can properly be understood as topical warrants for how to reach conclusions about public protection. On one hand, we have what I term the topos of the innocent bystander, which basically says that governments should intervene to protect innocent third parties, for example against smoking. This is legitimized on the basis of moral evaluation and is sometimes quoted with a reference to John Stuart Mill's saying that governments should only limit individual freedom in order to protect the freedom of others. On the other hand, this is counterbalanced by the topos of private and public, a common argument saying that only when private actions enter the public space should they be subject to government regulation. The second topos is backed by legitimation through authority (public and private domains). Also in this second part, the coupling and tensions between the two topoi play out as a struggle over numbers.

Many public health policies have a much broader field of intervention than a small issue like smoking bans. One should think that they could be framed all the more effectively, since these broad policies always generates large numbers of victims, e.g. in sickness and mortality rates, on the basis of the entire population. This can easily lead to somewhat diffuse perception of political arguments, however, if everybody appears to be victims and villains at the same time. Ever since its emergence in the mid-1970s, the aim of the new public health discourse has been to give individuals back the responsibility for their own health, which 'medicalization' had allegedly deprived them of (cf. Larsen 2009b). Social responsibility for health was not rejected or essentially diminished, but the proliferation of this discourse did have the side effect of making everyone seem somewhat guilty of their own fate, because poor health status was presented as the result of individual lifestyle choices.

My suggestion here is that the rapid impact of the smoking ban frame may result from a shift from previously seeing it as a broader public health issue to 
now focusing almost entirely on smoking bans as a workplace safety regulation. The difference is that in the workplace, workers are generally seen as bystanders to the requirements set by employers, whereas their unhealthy lifestyles in general are rather seen as the result of individual choices. Therefore, proponents of smoking bans have rejuvenated older symbols and arguments like 'workers rights' (Smoke Free Partnership, 2006, p. 7) to speak on behalf of a smaller and more well defined group of victims. This way of framing smoking bans also makes it easier for health advocacy groups to build knowledge-based alliances with the labor unions and trade unions against the economic interests of the tobacco industry.

The retrospective article by the British anti-tobacco group ASH also shows how it has been a deliberate strategy to 'split the opposition' against smoking bans, which in this case means to analyze the respective preference sets of the main actors in the field and then to isolate the tobacco industry from its previous allies such as trade and labor unions (Arnott et al., 2007). At least for the UK, this selection of victim groups and possible allies in the political struggle is perhaps also what can account for the timing of the smoking ban. While organizations in the public health lobby such as the British medical Association and the Royal College of Physicians had long been in favor of a comprehensive smoking ban, the policy shift did not occur until labor and trade unions came along in addition to the Labour government of course (Arnott et al., 2007).

A strong symbolic representation of victimized workers appears on an official departmental article announcing the UK adoption of a comprehensive workplace smoking ban (Department of Health, 2006b). The cover photograph shows an African-American child with the face covered in smoke. The imagery is equally powerful and confusing, because while it is the perfect image of an innocent victim unfairly put at risk, a smoking ban in bars and restaurants will hardly affect the health status of many 1-year olds (childcare services were already smokefree before). None of the smoking ban documents illustrate bartenders themselves, while the child conveys the image of an innocent bystander being subjected to the will and harm of others. In addition, the choice of skin color also suggests that second hand smokers constitute a repressed minority group.

Another dimension of the smoking ban frame is the selective focus on public places and the hospitality industry in particular as opposed to second-hand smoking in general. Obviously, it is less controversial to regulate second-hand smoke in public than in private homes not to mention easier to enforce, but with respect to the presentation of numbers, the arguments are again highly selective according to what fits the topical landscape.

In the 2006 report, the Smoke Free Partnership published estimated death tolls attributable to second hand smoking, which were reported in several media to indicate how many lives a new smoking ban could save each year. Strangely enough, the far majority of deaths are caused by exposure to second hand smoking in private homes, which are not covered by the proposed smoking ban. These estimates are by definition difficult to calculate, but at least in this section, the figures of the Smoke Free Partnership are not (visibly) biased to indicate a larger risk.

As an example of how these figures are used in crafting political arguments, the public discussion around the first proposal for a Danish smoking ban was presented in the spring of 2006 and partly based on these exact numbers from the Smoke Free Partnership. In several National media, the government 
said that it wanted to do something about the 1.714 Danes dying from second hand smoke every year, and therefore the Government's proposal was to prohibit smoking in bars and restaurants.

What was left out from the argument was that according to the exact same source, only three individuals $(0.17 \%)$ out of 1.714 are estimated to die from second hand smoking in bars and restaurants. If we include exposure in all workplaces, the proportion rises to $397(23.2 \%)$ of all deaths, while the rest $(76.8 \%)$ are exposed at home (Smoke Free Partnership, 2006, p. 28). If the numbers are limited to non-smokers, the estimated saved lives amount only to one person exposed in the hospitality sector and 137 for all workplaces (Smoke Free Partnership, 2006, p. 34). On a European scale, the proportions are roughly the same. Deaths attributable to exposure in the hospitality sector are negligible, whereas deaths in all workplaces combined constitute a little more than nine percent of all deaths attributable to second hand smoking (Smoke Free Partnership, 2006, pp. 27-38).

The point here is only to highlight the discrepancy between the promise of 1.714 saved lives and the one singular non-smoker who can expect to live as a result of smok free bars and restaurants, and this is according to the same data not to forget. The conclusions are not drawn from raw data, in other words, by they are warranted by the topos of the innocent bystander, whose effectiveness as a political argument builds on the well-known imagery of victims of repression. It is difficult to document the selective use of death tolls and their effect across all European countries, but the proportions between the different risk groups are comparable (Smoke Free Partnership, 2006, pp. 17-41) and yet, all the countries examined pay almost all their attention to smoking bans in bars and restaurants as the preferred space of regulation. The general tendency is that public place smoking bans are framed as being the natural solution to the death tolls of second-hand smoking, while the underlying evidence suggests that only a tiny proportion of these deaths can actually be avoided if the ban is initiated as planned.

Even radical health advocacy groups systematically avoid the question of regulating smoking in private homes, e.g. to protect children from second-hand smoke, although the end goal is still seen as the 'tobacco free society' (Roemer, 2004). Why is the private sphere not even mentioned? It is obviously difficult to analyze the silences of any given discourse without some degree of speculation, but since these policies are presented as being science-driven, it is noteworthy when major parts of the same evidence is plainly ignored. Based of the policy documents used in this analysis, however, it is at least possible to consider three main reasons why public places are framed as the main problem.

First, enforcing a smoking ban in private homes is notoriously difficult. The US prohibition era underlined what other problems can result from giving smugglers and organized crime a new market opportunity and in spite of considerable differences between alcohol and tobacco regulation, both areas share the topical division between private and public spaces. Second, the process of gathering support and legitimacy for severe private regulation is much more demanding than it is in workplaces. Third, most countries already have a tradition for a more strict regulation of phenomena traditionally associated with 'sinful' behavior in urban areas such as drinking, gambling and prostitution, and no less in liberal regimes such as the British. By limiting itself to public places and by focusing particularly on bars and restaurants, smoking bans borrow into the traditional legitimacy of this field of regulation. 
In terms of the two different topoi, one could argue that the limited focus on public spaces in the discussion of smoking bans represents the only way to align two otherwise conflicting principles. While the first topos warrants public intervention whenever the well-being of innocent bystanders is at stake, the second only warrants regulation in public places. By focusing on the workplace, the tension between the two principles is lessened considerably, which is why the prospects of implementing smoking bans are likely to be much higher in workplaces than elsewhere. Again, the main argument is that smoking bans do not simply represent a causal effect of a clear and well-identified objective problem, but are the result of a very selective framing of smoking bans designed to convey such an image.

\section{Conclusion}

Europe has witnessed a new wave of public place smoking bans, which is likely to extend to more countries in the following years, mainly because the arguments used successfully in the UK or Norway could apply just as well to bartenders in Bavaria and Eastern Europe. The main focus of this article has been on what can explain this wave of policy shifts. In order to approach a fuller understanding of this policy development, the article devoted some attention to question some usual explanations in political science as well as the self-understood explanations of anti-tobacco networks and government health departments, in particular the broadly accepted idea that smoking is banned because we now know how dangerous it is. It is similarly problematic to explain the wave of smoking bans as the singular cause of shared fundamental beliefs in the health benefits of smoke free environments. There is indeed a shared belief that smoking causes cancer, but it has existed for decades and does not itself explain the current shift unless we look more closely at the ways in which such beliefs are strategically crafted into political arguments.

Alternatively, this article claims that the urgent impact of smoking bans owes at least some of its imminent force to the selective framing of second hand smoking. Rather than focus on the big picture of tobacco as such, anti-tobacco advocates and governmental health departments have successfully shaped knowledge on smoking as to demarcate a limited sphere of legitimate but very urgently needed intervention, but which still draws on numbers, symbols and arguments from the broader problem of smoking. Several tools of this particular problem frame have been described, including at least two vital components.

First, the policy frame of smoking bans argue that since knowledge does not speak for itself, anti-tobacco advocates should take it upon themselves to tell us what it means while attacking the truth status of all evidence that compromises the advocacy of smoking bans. This was analyzed by the dual topoi of scientism and knowledge as a weapon in order to fully understand the complex interchanges between science and biased opinions in the area of tobacco control. Second, the frame of workplace safety regulations has provided smoking bans with a window of legitimate intervention as well as a well-defined group of innocent victims. The selective framing of victims is also seen in the dedicated focus on public spaces, which does not build directly on risk evidence, but on what forms of intervention cause the least resistance. 
While this is characterized as one policy frame here, it does not necessarily constitute a neat unity in which everything fits perfectly. As the discussion of the four identified topoi suggests, there are clear argumentative tensions within the frame, and the analytical significance of these tensions cannot be underestimated. Adding the topical analysis has the advantage of making it clear that in cases like smoking and health, we should not be fooled into a bold opposition between science on one hand and the rigidity of cultural norms on the other. Such dichotomous narratives are false and can be dismantled in various kinds of critical discourse analysis (cf. Wodak, 1999, p. 186) in order to appreciate the truly political functions of policy frames and their complexity. The inner complexity of the policy frame also means that future development can take unexpected turns. As mentioned in the introduction, extreme cases like the present example from California are often used to project images of the future policy paths. There is no direct path from these smoking bans to some kind of police state, however, so perhaps we should be most concerned with the swift translation of 'facts' into political arguments.

However, knowing the end goal of anti-tobacco networks to be a tobacco free world, it is tempting to speculate that public place smoking bans can also function as some type of Trojan horse. When the regulation of public spaces has become normalized and widely accepted, suddenly the initial selectiveness of these death tolls will look like an urgent, objective problem in need of a solution. Since the initial framing of public place death tolls was so highly selective, it would be easy to look at these numbers later on and argue that a public place smoking ban is totally out of balance with the evidence, because second-hand smoking kills ten times as many in private homes every year. 


\section{References:}

Arnott, D. et al. (2007). Comprehensive smoke-free legislation in England: how advocacy won the day. Tobacco Control, 16: 423-428.

Baumgartner, F. R. \& Jones, B. D. (1993). Agendas and Instability in American Politics. Chicago: The University of Chicago Press.

de Beyer, J. \& Bridgen, L. W. (2003). Tobacco Control Policy. Strategies, Successes, and Setbacks. Washington: The International Bank for Reconstruction and Development.

Blyth, M. (2002). Great Transformations. Economic Ideas and Institutional Change in the Twentieth Century. Cambridge: Cambridge University Press.

Boyle, P. et al. (eds.) (2004). Tobacco - Science, Policy and Public Health. Oxford: Oxford University Press.

Chong, D. \& Druckman, J. (2007). Framing Theory. Annual Review of Political Science 10: 103-26.

City of Calabasas (2006). Ordinance No. 2006-217. An ordinance of the city of Calabasas regulating second-hand smoke and amending the Calabasas Municipal Code. http://www.cityofcalabasas.com/secondhandsmoke.html (URL consulted Nov 11, 2008).

Department of Health (2004). Public Health (Tobacco) Act. Dublin: Department of Health.

Department of Health (2006a). Health Bill 76. London: House of Lords, the Stationary Office.

Department of Health (2006b). Reducing exposure to secondhand smoke. London: Department of Health.

Entman, R. M. (1993). Framing: towards clarification of a fractured paradigm. Journal of Communication, 43(4): 51-8.

Feldman, E. A. \& Bayer, R. (2004). Introduction: Liberal States, Public Health, and the Tobacco Question. In Feldman, E. A. \& Bayer, R. (Eds.), Unfiltered. Conflicts over Tobacco Policy and Public Health (pp. 1-7). Cambridge: Harvard University Press.

Fischer, F. (2003). Reframing Public Policy. Oxford: Oxford University Press.

Foucault, M. (1969). L'archéologie du savoir. Paris: Gallimard.

Frankenberg, G. (2004). Between Paternalism and Voluntarism: Tobacco Consumption and Tobacco Control in Germany. In Feldman, E. A. \& Bayer, R. (Eds.), Unfiltered. Conflicts over Tobacco Policy and Public Health (pp. 161-89). Cambridge: Harvard University Press.

Goldstein, J. \& Keohane, R. O. (1993). Ideas and Foreign Policy: An Analytical Framework. In Goldstein, J. \& Keohane, R. O. (Eds.), Ideas and Foreign Policy Beliefs, Institutions, and Political Change (pp. 3-30). Ithaca: Cornell University Press.

Grue, J. (2009). Critical discourse analysis, topoi and mystification: disability policy documents from a Norwegian NGO. Discourse Studies 11(3): 305-328.

Haas, P. M. (1992). Introduction: Epistemic Communities and International Policy Coordination. International Organization, 46(1): 1-35.

Hajer, M.A. \& Laws, D. (2006). Ordering through discourse. In Moran, P. et al. (Eds.), The Oxford Handbook of Public Policy (pp. 251-68). Oxford: Oxford University Press.

Hall, P. A. (1993). Policy Paradigms, Social Learning, and the State. The

Case of Economic Policy-making in Britain. Comparative Politics 25(3): 275-96. 
Helsedepartementet (2003). Proposisjon nr. 23 (2002-2003). Oslo: Helsedepartementet.

Jäger, S. \& Maier, F. (2009. Theoretical and Methodological Aspects of Foucauldian Critical Discourse Analysis and Dispositive Analysis. In Wodak, R. \& Meyer, M (Eds.), Methods of Critical Discourse Analysis (pp. 34-61). London: Sage.

Jha, P. et al. (2004). Effective interventions to reduce smoking. In Boyle, P. et al. (Eds.), Tobacco - Science, Policy and Public Health (pp. 733-48). Oxford: Oxford University Press.

Joossens, L. \& Raw, M. (2006). The Tobacco Control Scale: a new scale to measure country activity. Tobacco Control 15: 247-253.

Joossens, L. \& Raw, M. (2007). Progress in Tobacco Control in 30 European Countries 2005 to 2007. Report presented at the $4^{\text {th }}$ European Conference on Tobacco or Health 2007, Basel, Switzerland, 11-13 October 2007.

Kingdon, J. W. (1984). Agendas, Alternatives and Public Policies. New York: Harper Collins.

Koop, E. C. (2004). Preface. Tobacco: The public health disaster of the twentieth century. In Boyle, P. et al. (Eds.), Tobacco - Science, Policy and Public Health (pp. v-xvii). Oxford: Oxford University Press.

Larsen, L. T. (2008). The Political Impact of Science: Is Tobacco Control Scienceor Policy-driven? Science and Public Policy 35(10): 757-69.

Larsen, L. T. (2009a): The Tactical Displacement of Ideas, or why I am Becoming Lakatos Intolerant. Working paper, Department of Political Science, University of Aarhus.

Larsen, L. T. (2009b): Knowledge into Action: A Genealogy of Public Health Policy in Denmark and the United States 1975-2005. Saarbrücken: VDM Verlag.

Leeuwen, T. v. (2007). Legitimation in discourse and communication. Discourse \& Communication 1(1): 91-112.

Leeuwen. T. v. \& Wodak, R. (1999). Legitimizing Immigration Control: A Discourse-Historical Analysis. Discourse Studies 1(1): 83-118.

Marmor, T. R. (2006). Review essay. Book Review Symposium on the Politics of Tobacco. Journal of Health Politics, Policy and Law 31(2): 375-84.

Marmor, T. R. \& Lieberman, E. S. (2004). Tobacco Control in Comparative Perspective: Eight Nations in Search of an Explanation. In Feldman, E. A. \& Bayer, R. (Eds.), Unfiltered. Conflicts over Tobacco Policy and Public Health (pp. 275291). Cambridge: Harvard University Press.

Nathanson, C. A. (1999). Social Movements as Catalysts for Policy Change: the Case of Smoking and Guns. Journal of Health Politics, Policy and Law 24(3): 421-88.

Nathanson, C. A. (2005). Collective Actors and Corporate Targets in Tobacco Control: A Cross-National Comparison. Health Education \& Behavior 32(3): 33754.

NYC Health (2002). New York City Smoke-Free Air Act of 2002. New York: New York City Department of Health and Mental Hygiene.

Office of Tobacco Control (2005). Smoke-Free Workplaces in Ireland: A OneYear Review. Clane: Office of Tobacco Control.

Regeringen (2007). Law on Smokefree Environments (law no. 512 of June 6 2007). Copenhagen: Department of Health and Domestic Affairs.

Rein, M. \& Schon, D. (1994). Frame Reflection. Toward the Resolution of Intractable Policy Controversies. New York: Basic Books. 
Reisigl, M. \& Wodak, R. (2009). The Discourse-Historical Approach (DHA). In Wodak, R. \& Meyer, M (Eds.), Methods of Critical Discourse Analysis (pp. 87121). London: Sage.

Rhodes, R.A.W. \& Marsh, D. (1992). New directions in the study of public policy networks. European Journal of Political Research 21: 181-205.

Roemer, Ruth (2004) A brief history of legislation to control the tobacco epidemic. In Boyle, P. et al. (Eds.), Tobacco - Science, Policy and Public Health (pp. 67794). Oxford: Oxford University Press.

Sabatier, P. A. (1993). Policy Change over a Decade or More. In Sabatier, P. A. \& Jenkins-Smith, H. C. (Eds.), Policy Change and Learning. An Advocacy Coalition Approach. (pp. 13-39). San Francisco: Westview Press.

Samet, J. M. (2004). Passive Smoking and Health. In Boyle, P. et al. (Eds.), Tobacco - Science, Policy and Public Health (pp. 287-313). Oxford: Oxford University Press.

Schattschneider, E.E. (1975): The Semisovereign People. A Realist's View of

Democracy in America. London: Thomson Learning.

Smoke Free Partnership (2006). Lifting the smokescreen. 10 reasons for a smoke free Europe. Brussels: European Respiratory Society.

Smoke Free World (2008). Website tracking tobacco control policies in various countries and US states, http://www.smokefreeworld.com/usa.shtml (URL consulted Nov 11, 2008).

Snow, D.M. \& Benford, R.D. (1988) Ideology, frame resonance, and participation mobilization. International Social Movement Research 1, 197-217.

Socialdepartementet (2003). Regeringens Proposition 2003/04:65. Rökfrie serveringsmiljöer. Stockholm: Socialdepartementet.

State of New York (2003). Clean Indoor Air Act. Public Health Law Section 1399. Albany: New York State Department of Health.

State of New York (2004). First Annual Independent Evaluation of New York's Tobacco Control Program. Albany: New York State Department of Health.

Stone, D. (2002). Policy Paradox. The Art of Political Decision Making. New York: Norton.

Studlar, D. T. (2002). Tobacco Control. Comparative Politics in the United States and Canada. Peterborough: Broadview Press.

Studlar, D. T. (2007). What Explains Policy Change in Tobacco Control Policy in Advanced Industrial Democracies? Working paper, Department of Political Science, University of Aarhus.

de Villepin, D. (2006). Intervention du Premier Ministre du 8 octobre 2006. Interview on 'Grand Jury' - LCI/RTL/Le Figaro, http://www.tabac.gouv.fr/article.php?id_article=192 (URL consulted July 18 2007).

Wodak, R. (1999). Critical Discourse Analysis at the End of the $20^{\text {th }}$ Century, Research on Language and Social Interaction 32(1\&2): 185-193.

Wodak, R., de Cillia, R., Reisigl, M., \& Leibhart, K. (1999). The Discursive Construction of National Identity. Edinburgh: Edinburgh University Press.

Wodak, R. \& Reisigl, M. (2000). Discourse \& Discrimination: Rhetorics of Racism \& Antisemitism. London: Routledge.

Wolfson, M. (2001). The Fight against Big Tobacco. The Movement, the State, and the Public's Health. New York: de Gruyter.

WHO (2003) Framework Convention on Tobacco Control. Geneva: World Health Organization. 
WHO (2004). Tobacco Control Legislation: an introductory guide. Second edition. Geneva: World Health Organization. 
Table 1: Public place smoking bans in eight European countries

\begin{tabular}{|c|c|c|c|c|c|c|}
\hline & $\begin{array}{l}\text { Year } \\
\text { en- } \\
\text { acted }\end{array}$ & $\begin{array}{l}\text { Public place } \\
\text { ban }\end{array}$ & $\begin{array}{l}\text { Work- } \\
\text { place ban }\end{array}$ & $\begin{array}{l}\text { Main rea- } \\
\text { son indicat- } \\
\text { ed }\end{array}$ & $\begin{array}{l}\text { To- } \\
\text { bacco } \\
\text { Con- } \\
\text { trol } \\
\text { Scale } \\
\text { Score } \\
2005 \\
\end{array}$ & $\begin{array}{l}\text { To- } \\
\text { bacco } \\
\text { Con- } \\
\text { trol } \\
\text { Scale } \\
\text { Score } \\
2007 \\
\end{array}$ \\
\hline Ireland & 2004 & $\begin{array}{l}\text { Comprehen- } \\
\text { sive }\end{array}$ & $\begin{array}{l}\text { Compre- } \\
\text { hensive }\end{array}$ & $\begin{array}{l}\text { Public } \\
\text { health }\end{array}$ & 74 & 74 \\
\hline Norway & 2004 & $\begin{array}{l}\text { Comprehen- } \\
\text { sive }\end{array}$ & Partial & $\begin{array}{l}\text { Workplace } \\
\text { health }\end{array}$ & 71 & 66 \\
\hline Sweden & 2005 & Partial & $\begin{array}{l}\text { Not in- } \\
\text { cluded }\end{array}$ & $\begin{array}{l}\text { Public } \\
\text { health }\end{array}$ & 60 & 61 \\
\hline Italy & 2005 & Partial & $\begin{array}{l}\text { Not in- } \\
\text { cluded }\end{array}$ & $\begin{array}{l}\text { Gastrono- } \\
\text { my/ } \\
\text { public } \\
\text { health }\end{array}$ & 57 & 57 \\
\hline $\begin{array}{l}\text { United } \\
\text { Kingdom }\end{array}$ & 2007 & $\begin{array}{l}\text { Comprehen- } \\
\text { sive }\end{array}$ & $\begin{array}{l}\text { Compre- } \\
\text { hensive }\end{array}$ & $\begin{array}{l}\text { Public } \\
\text { health }\end{array}$ & 73 & 93 \\
\hline Denmark & 2007 & Partial & Partial & $\begin{array}{l}\text { Workplace } \\
\text { health }\end{array}$ & 45 & 45 \\
\hline $\begin{array}{l}\text { Germa- } \\
\text { ny }\end{array}$ & 2007 & $\begin{array}{l}\text { Mini- } \\
\mathrm{mal} / \text { partial }\end{array}$ & $\begin{array}{l}\text { Not in- } \\
\text { cluded }\end{array}$ & $\begin{array}{l}\text { Workplace } \\
\text { health }\end{array}$ & 36 & 37 \\
\hline France & $\begin{array}{l}2007 / \\
8\end{array}$ & Partial & $\begin{array}{l}\text { Compre- } \\
\text { hensive }\end{array}$ & $\begin{array}{l}\text { Public } \\
\text { health }\end{array}$ & 56 & 59 \\
\hline $\begin{array}{l}\text { Nether- } \\
\text { lands }\end{array}$ & 2008 & Partial & Partial & $\mathrm{n} / \mathrm{a}$ & 52 & 50 \\
\hline
\end{tabular}

